\title{
Identification and Risk Management In The Expenditure Process: Risks Leading to Deadline Slippage and Costs, and Building Projects
}

\author{
Abdelhak Challal \\ Studies and Research Laboratory in Applied Mathematics (LERMA) \\ Mohammed V University- Mohammadia School of Engineering Rabat, Agdal Morocco \\ Mohamed Tkiouat \\ Studies and Research Laboratory in Applied Mathematics (LERMA) \\ Mohammed V University- Mohammadia School of Engineering Rabat, Agdal Morocco
}

\begin{abstract}
The objective of this research is the design of a mapping of risks which are mainly related to the processes of expenditure. The research also serves to identify the actions and the necessary measures to control risks and the delays of completing a construction project. The literature from the last two decades related to this field was examined. A quantitative analysis of risks in the expense process of building projects sample representing various regions of Morocco allows identifying the risks and ranking them by determining their occurrences and impacts. Eight major risks, 43 measures, 52 actions and 10 performance indicators are linked to these risks have been identified.
\end{abstract}

Abstrak: Tujuan penelitian ini adalah desain dari pemetaan risiko yang terutama berkaitan dengan proses pembelanjaan. Penelitian ini juga berfungsi untuk mengidentifikasi tindakan dan langkah-langkah yang diperlukan untuk mengendalikan risiko dan penundaan dalam menyelesaikan proyek konstruksi. Literatur dari dua dekade terakhir berkaitan dengan bidang ini diuji. Sebuah analisis kuantitatif dari risiko dalam proses biaya pembangunan proyek sampel, yang mewakili berbagai daerah di Maroko memungkinkan mengidentifikasi risiko dan peringkat mereka dengan menentukan kejadian dan dampaknya. Delapan risiko besar, 43 langkah-langkah, 52 tindakan dan 10 indikator kinerja yang terkait dengan risiko telah diidentifikasi.

Keywords: action; delay; indicator; mapping; measure; risk 


\section{Introduction}

The problem of delays in the field of construction is a common phenomenon worldwide. In Saudi Arabia, Assaf and AlHejji (2006) found that only 30 percent of construction projects have been completed within the contracted deadlines, and the average slipping period was between 10 percent and 30 percent. In Nigeria, Ajanlekok (1987) identified through a questionnaire survey the delays' effects on 61 construction projects. The results demonstrated that deadline slippage and cost overruns were frequent and quite significant. The project manager is generally responsible for those causes. Odeyinka and Yusif (1997) also illustrated that 7 projects out of 10 studied had experienced deadline slippage during their execution. Chan and Kumaraswamy (1997) studied the delays in industrial construction in Hong Kong. They underlined the success index of a project and its delivery within the deadlines, respecting the quality norms and the budget allotted to it.

Normally, when we realize that the projects will experience some deadline slippage, we provide a deadline extension or we accelerate the pace of the works execution. As a consequence, we allow for additional expenses, normal practices which generally permit an addition of a supplementary cost percentage based on a prior study. Time performance is one of the key measures of the project's success.

According to Faridi and El-Sayedgh (2006) delays have a negative impact on the success of the project in terms of time, cost, quality and security. For Aibium and Jagbor (2002) the entrepreneur and the Project Manager are jointly or separately responsible for the delay in executing construction projects. The delays cannot be minimized unless their causes are known, and in order to have an accurate estimate of costs and deadlines, reliable methods and commonly agreed practices must be applied. Faridi and El-Sayedgh (2006) also emphasized that these causes must be controlled during the life time of the project. Moreover, an important economy of resources can be obtained while identifying and controlling the causes.

The main objectives of this study are as follows:

- Design a mapping of risks related to budgetary process and expenditure

- Identify the necessary actions and measures to control risks and delays of completing the construction projects

This article is organized as follows: Section 1 deals with the previous studies on the causes of deadline slippage in construction projects. Section 2 explains the methodology adopted. Section 3 discusses the results. Section 4 presents the elements of risks raised in the interview, Risk detail, Causes of risk and Identified incidents. Section 5 presents the actions and measures which minimize construction project delays. Section 6 presents the performance indicators that are related to them. Section 7 attempts to draw conclusions and perspectives.

\section{Literature Review}

Many articles and studies conducted on the causes of construction project delays worldwide have been examined. The risk identification process has been to identify, define and describe the risks or the risky events in the particular context of a project.

The risk identification also serves to spot the potential problems before getting real and to include this information in the project management process. The risk iden- 
tification process has allowed the creation of a list of risks that could have negative impact (threat) or positive ones (opportunities) in reaching the project objectives. The risks have been identified on the basis of hypothesis, plans and specifications and also the judgment of experts.

In Morocco, Challal and Tkiouat (2012) identified the causes of delay slippage that are seriously risky particularly in the estimation of the initial budget, the volatility of architecture program and engineering as well as building site risks. These findings were obtained on the basis of a quantitative analysis of delay risks in a sample of building projects that represents various parts of Morocco. Ubaid concluded in his surveys on the projects completed in Saudi Arabia that lack of entrepreneurial performance is one of the major causes of delays. He also identified the principle measures to reinforce resources and improve entrepreneurial skills. Assaf et al. (1995), Al-Ghafly (1995) observed that the major causes linked to construction projects in Saudi Arabia are due to financial problems, changes in project conception ,projects' contributions, delay in decisions-taking, getting owner's approval, difficulties in getting a work permit, communication and coordination problems. In Morocco, Challal and Tkiouat (2012) identified factors that lead to over- and underestimations: lack of price reference pricing, Lack of reference of works, lack of costing model, the changing needs and the insufficiency of prior studies.

Chan and Kumaraswamy (1997) have carried out a survey to evaluate the relative importance of 83 factors of potential delays in construction projects in Hong Kong. They observed that 5 major causes of deadline slippage related to mismanagement of risk, bad supervision, condition of the site, delay in taking decisions, varying customer needs, variation of working time. Kaming et al. (1997) has studied the causes of slippage of the completion date of 31 sky-scrappers in Indonesia. They noticed that cost overruns happen most frequently and are most significant than deadline slippage. They underlined that the main causes of this slippage are: the increase due to inflation, the underestimate of material cost as well as the degree of complexity of the construction project itself, those relating to slippage are: change of design conception, weak productivity, inadequate planning, shortage of resources. Kumaraswamy and Chan (1998) noted in a study that the causes in construction projects conducted in Honk Kong that there were differing perceptions by the different parties.

Noulmanee et al. (1999) concluded in a study on the causes of delays in the construction of highways in Thailand that the major causes are due to sub-contractors' incompetency and poor project conception (incomplete and inaccurate design) They also suggested that the delay could be minimized by devising a good project conception, close coordination and an effective communication among between the participants. Al-Momani (2000) in his survey on 130 public projects in Jordan pointed out that the main causes of delay are: poor project conception, climate, poor site management, delay in delivery, economic situation and the amendments. He recommended that managers of public projects take the necessary time to start carrying out thorough studies by using real quantitative data in order to formulate pertinent terms before starting attributing the said project.

The study also suggested that special attention be given to industrialists in the field of construction to reduce the purchasing costs. Consequently, the delays are essentially due to poor contractors' productivity. According to Koushk et al. (2005), Assaf and Al-Hejji 
(2006), Meeampol and Ogunlana (2006), Sambasivan and Soon (2007), Le-Hoai et al. (2008) deadline slippage could lead to a number of negative effects, such as cost overruns Sambasivan and Soon (2007), Towhid and Amiruddin (2011) noted that major delay consequences are related to arbitration conflicts, litigations, and total abandonment. Toor and Ogunlana (2008), and Tumi et al. (2009) believe that poor planning and lack of communication are the principle causes of deadline slippage in construction projects in Libya.

Hamidreza et al. (2010) qualified certain causes as unacceptable in order to respect the contractual deadline for the completion of the construction projects in Hong Kong. These causes are relative to delays of supply and subcontractors' incompetence. Haseeb et al. (2011) consider that to avoid delays, the project manager must settle the corporate discount on time. Also the enterprise must do the same thing for the subcontractors. Ogunlana et al. (1996) noticed that time and cost overruns in construction projects of sky-scrappers in Bankok and Thailand resulted from three factors: lack of infrastructure, default in payment by both customers and consultants, and contractors incompetency, they recommended that managers and associations specializing in the field of construction make more efforts to streamline and build the infrastructure which would allow easy supply of materials and boost efficiency in the field of construction. Frimpong et al. (2003) conducted a survey through a questionnaire on underground construction projects in Ghana in order to identify and evaluate the importance related to the factors leading to time and cost overruns of the said projects. The findings revealed that the main causes are: late payment on the part of the project managers, shortage of raw materials, implementation of obsolete construction processes, and the high cost of raw materials. They recommended that to minimize the delays in carrying out the construction works, the projects should be well in advance, and a follow-up must be insured as well as the control and respect of the accomplishment planning.

\section{Methodology}

\section{(Adopted: Limitations and Skills)}

The adopted methodology includes a 'top down' qualitative analysis. It allows highlighting the most important risks among all those will be identified. We seek to identify the risks to which the project is the most vulnerable, so that more attention and closer monitoring will be allowed. In the area of risk management, this analysis is generally raised by the level of probability of an event and the importance of impacts it will have on the project. The combination of the two serves to measure and judge the importance of an identified risk compared to others.

According to the "top-down" process adopted so far by the previous so-called macroscopic studies, and which helped to investigate and assess major risks on the macroprocess through documentary research, interviews, questionnaires, by starting the evaluation of frequent occurrences the severity and importance related to the causes by the contractors, the project manager, and the owners. These risks were ranked according to the retained criteria leading to the establish- 
ment of a mapping of risk causes. Also, 8 major causes were identified. The top-down approach certainly helps dispose of a risks mapping in a short time.

\section{Limitations}

The methodological elements used were inspired from the best practices and adapted to the context and level of maturity of the enterprises, the project manager and owners; as such it would help generate a mapping of causes and risks.

However, the success and efficiency of mapping the causes of deadline slippage is based on the ability of the enterprises, the project manger and the owners to put them into good effect. Nevertheless, these rules are reinterpreted according to the case and the objectives of those involved. The meth- odological elements must be considered as a dynamic base to be continually enriched by the participants on the basis of the specificities of their environments and the evolution of these environments in time.

\section{Reference Methodology of Overruns Causes Mapping}

\section{Definition of a Common Language}

One of the first actions that have been conducted during the initiation stage to practicing the mapping of causes of deadline slippage is to ascertain the existence of a framework which is clear and known to all.

This framework goes through the definition of a common language. So, the grids of reference that helped reconcile these requirements are as Table 1 and Figure 1.

\section{Table 1. Grid of Reference}

\begin{tabular}{llll}
\hline & Probability & \multicolumn{1}{c}{ Impact } \\
\hline Level 1 & Rare or very rare & Level 1 & Weak (0-4) \\
Level 2 & Regular/frequent & Level 2 & Moderate (4-7) \\
Level 3 & Very frequent to systematic & Level 3 & Strong (7-10) \\
\hline
\end{tabular}

Grid A 1: a summary of probability and assessment of risks
Grid A 2: a summary of assessment of potential risk impact 
Figure 1. Grid of Reference

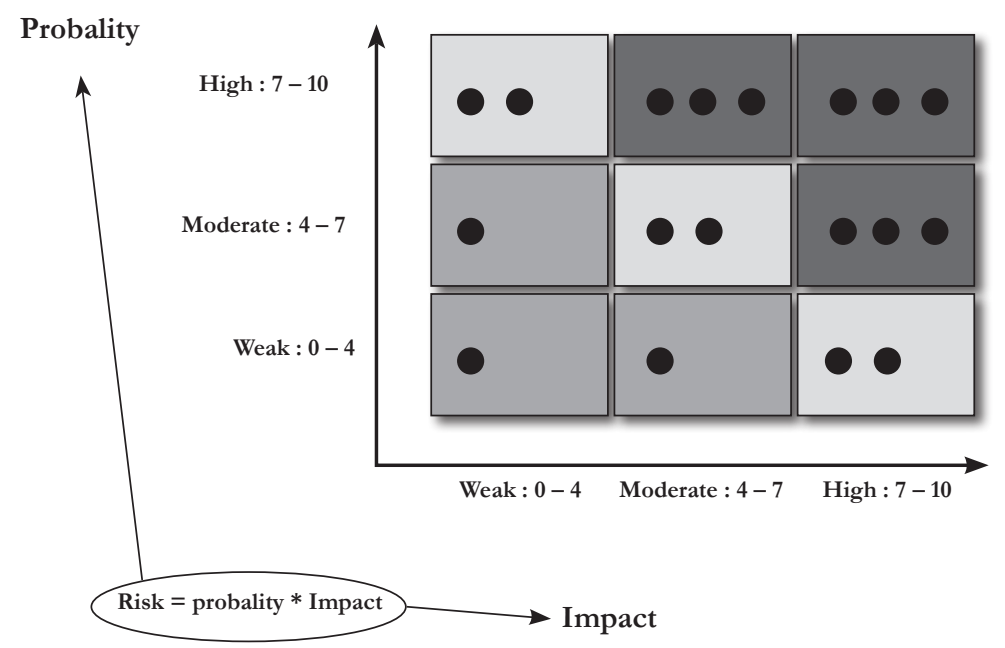

Grid A 3: a summary of severity evaluation

\section{Conduct of Interviews}

It is one of the key-stages of the process. The interviews are supposed to bring out the participants' maximum added-value. The main objective is to collect the participants' vision and perception concerning the most critical causes of deadline slippage, the key measures that should be taken or could minimize the risk causes identified.

\section{Formalization and Validation of the List of Major Risks}

Once the interviewing stage finished, an inventory of all the causes of deadline slippage has been carried out so that they should be reprocessed them again, synthesized and regrouped them into a family of causes called "grouped" or "major." This stage is essential as it will help to work on these causes in a structured and more efficient way, while establishing the link between the practical fieldrelated issues raised by the participants in the questionnaire or during the interviews, pointing out the consequences of the potential risks on the participants' objectives. The number of causes of major risks could basi- cally vary from one mapping process to another. Hence, nevertheless a good practice is set between the ranges of 5 to 25 .

\section{Ranking of Risks}

A number of workshops on ranking of risks have been held (one or several participants by category). These workshops constituted the "object" of the process as the participants will express their views on the assessment of each major risk. It should be noted, however, that such a workshop is not based on a "scientific" or statistical analysis of risks, but on the different participants' perception of risk. Hence the crucial nature of the "casting" stage previously mentioned. Participants must be clearly reminded that by nature they generally tend to base their evaluation on tangible data and figures. Besides, if for some risks the participants use a "basis" listing all the incidents which have occurred ("recognized" risks) the latter could be taken account of as a need on this level of perception, notably as far as the criterion of the probability of occurrence is concerned. 


\section{Mapping Formalization}

Beyond the mapping itself (a graph composed of two axes: impact and probability) it is always important to analyze the votes by way of statistics (of average impact and probability, variances measuring the scattering of votes on a particular risk/a given criterion, etc.)

\section{The Research Findings}

\section{Ranking the Delay Causes Using the Ishikawa Diagram}

The Ishikawa Diagram (Figure 2), also known as the cause-effect diagram, is a tool to present the possible causes of a particular problem systematically in a graph. These problems are presented on two detailed and different levels in the fish bone diagram. The top case of the diagram contains the presentation of the problem.

\section{Frequency of Delay Causes}

The most frequent causes are related to insufficiency or absence of prior studies and feasibility of the projects, errors made in the initial budget assessment errors arrangement, errors of piloting and coordination in the study phase and during the construction period, volatility in the architecture and engineering program (multiple modification requests) external delay procedures (granting subsidies, issuing construction permits etc.) failure of some participants, working site hazards as mentioned in Table 1.

\section{Severity of Delay Causes}

The most serious deadline slippages are due to a number of causes, as mentioned in Table 2.

Figure 2. The Identified Risks in the Expenditure Process Can Lead to Deadline Slippage in the Construction Projects

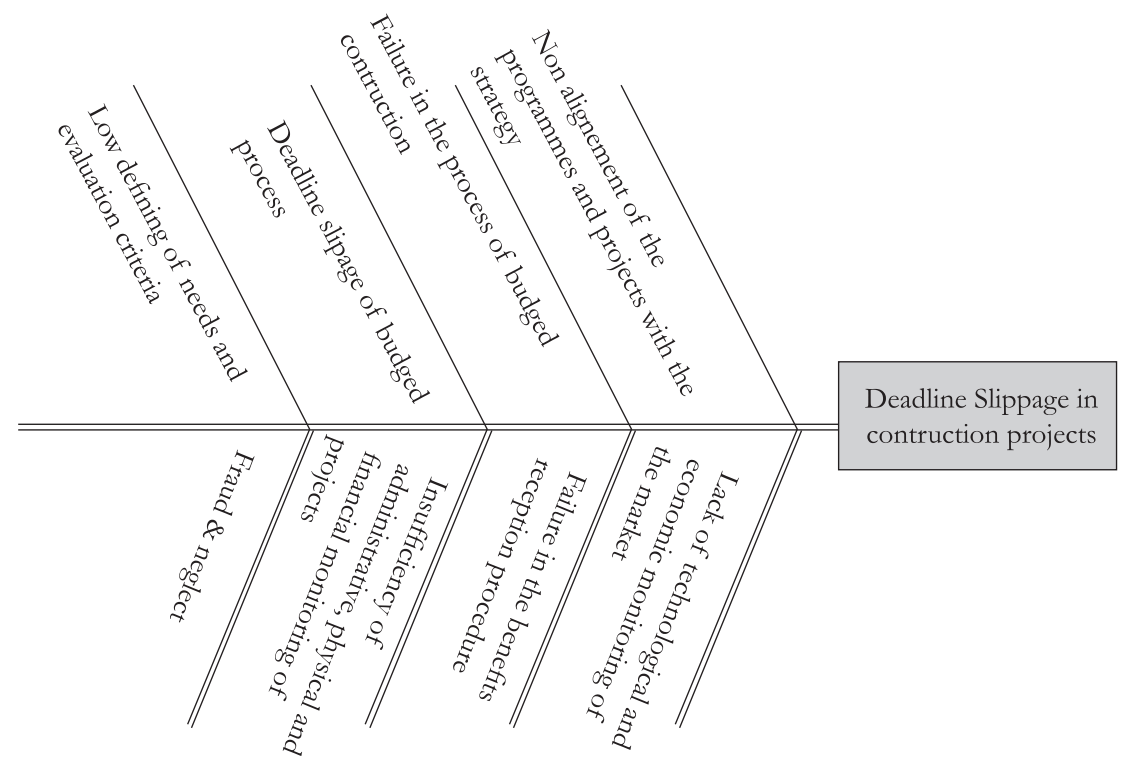


Table 2. Frequency, Impact, Criticality of Causes

\begin{tabular}{|c|c|c|c|c|}
\hline No Risk & Name & Impact & Probability & Criticality \\
\hline $\mathrm{R} 1$ & $\begin{array}{l}\text { Non alignment of the programs and } \\
\text { projects with the strategy }\end{array}$ & 2.6 & 8.2 & 21.32 \\
\hline $\mathrm{R} 2$ & Failure in the process of budget construction & 4.6 & 7.5 & 34.5 \\
\hline $\mathrm{R} 3$ & Deadline slippage of budget process & 8.5 & 8 & 68 \\
\hline $\mathrm{R} 4$ & $\begin{array}{l}\text { Low defining of needs and evaluation } \\
\text { criteria }\end{array}$ & 4.5 & 8 & 36 \\
\hline $\mathrm{R} 5$ & $\begin{array}{l}\text { Lack of technological and economic } \\
\text { monitoring of the market }\end{array}$ & 7.5 & 8 & 60 \\
\hline R6 & Failure in the benefits reception procedure & 3 & 7.4 & 22.2 \\
\hline $\mathrm{R} 7$ & $\begin{array}{l}\text { Insufficiency of administrative, physical and } \\
\text { financial monitoring of projects }\end{array}$ & 4.2 & 8.5 & 35.7 \\
\hline $\mathrm{R} 8$ & Fraud \& neglect & 3.8 & 7.8 & 29.64 \\
\hline
\end{tabular}

Figure 3. Reference of the Criticality Assessment Risk

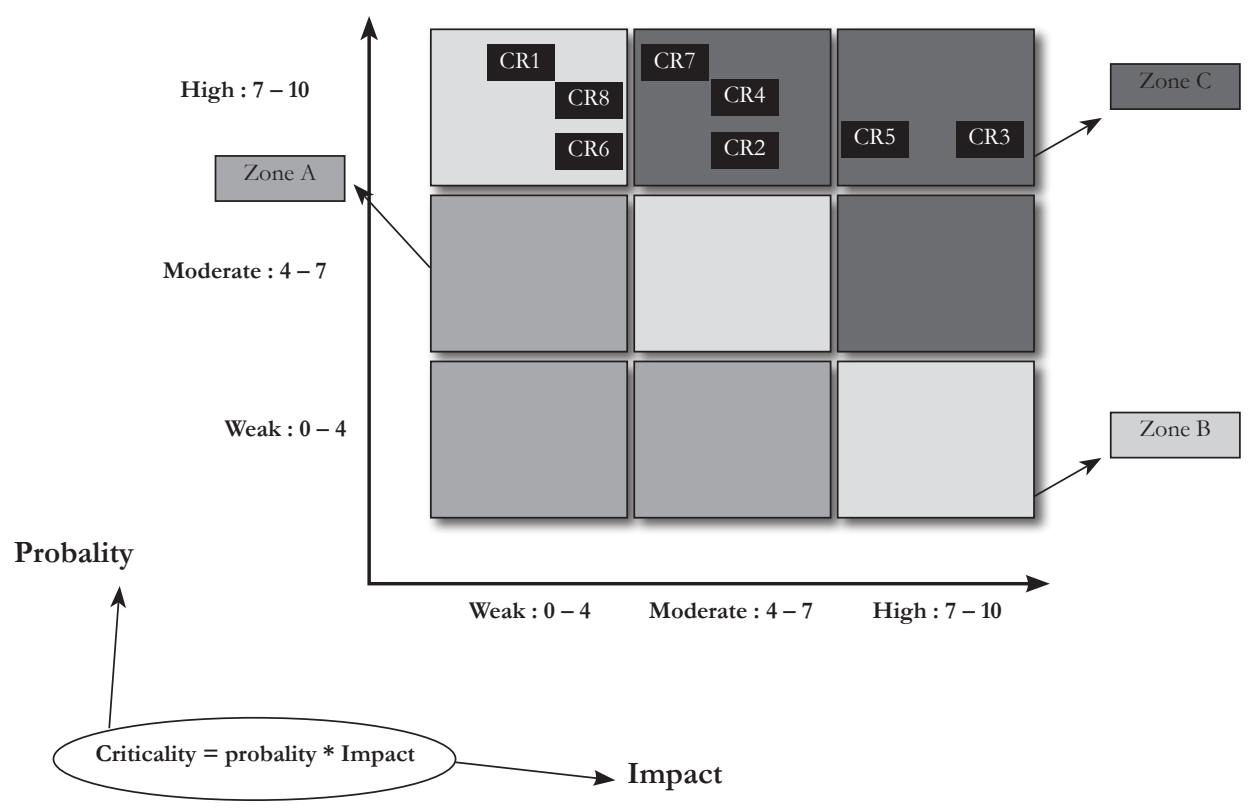

According to the grid reference of the criticality risk assessment, 5 risks have been found in zone $\mathrm{C}$ (a high-risk zone), 3 risk in zone B (moderate risk zone) (see Figure 3). 


\section{Elements of Risks Raised}

\section{In the Interview, Risk Detail, Causes of Risk, Identified Incidents and Indicators}

The elements of risks raised in the interview, risk detail, causes of risk and Identified incidents are listed in Table 3.

\section{Table 3. Risk Detail, Causes of Risk, Identified Incidents and Indicators}

\begin{tabular}{|c|c|c|c|c|}
\hline & & $\begin{array}{l}\text { Risk } 1 \text { : Non alignment } \\
\text { of programs and } \\
\text { projects with the strategy }\end{array}$ & $\begin{array}{l}\text { Risk } 2 \text { : failure in the process of } \\
\text { budget construction }\end{array}$ & $\begin{array}{l}\text { Risk } 3 \text { : deadline } \\
\text { slippage of budget } \\
\text { process }\end{array}$ \\
\hline 1) & $\begin{array}{l}\text { Elements } \\
\text { of risks } \\
\text { raised in the } \\
\text { interview }\end{array}$ & $\begin{array}{l}\text { Non formalization } \\
\text { of the programs and } \\
\text { projects }\end{array}$ & $\begin{array}{l}\text { Transfers of appropriation } \\
\text { since the beginning of the } \\
\text { exercise } \\
\text { Insufficient follow up of the } \\
\text { appropriations carried over } \\
\text { projects that are inadequately } \\
\text { identified lead to induced costs }\end{array}$ & $\begin{array}{l}\text { - Delegations of late } \\
\text { appropriations }\end{array}$ \\
\hline 2) & Risk detail & $\begin{array}{l}\text { Non formalization of } \\
\text { projects and programs } \\
\text { that can lead to } \\
\text { discrepancies in terms } \\
\text { of alignment with the } \\
\text { strategy } \\
\text { - The absence of cause } \\
\text { to effect link between } \\
\text { the programmes and } \\
\text { the strategy }\end{array}$ & $\begin{array}{l}\text { The failure in the planning } \\
\text { is caused by the absence of } \\
\text { framework that allows the } \\
\text { visibility of actors and to set a } \\
\text { budget discussion exercise based } \\
\text { on objective basics. It depends } \\
\text { also on the capacity to form } \\
\text { programs and projects into actions } \\
\text { limited by time, with a precise } \\
\text { budgets and concrete results }\end{array}$ & $\begin{array}{l}\text { Deadline slippage of } \\
\text { budget process }\end{array}$ \\
\hline 3) & $\begin{array}{l}\text { Causes of } \\
\text { risk }\end{array}$ & $\begin{array}{l}\text { Appropriation transfers } \\
\text { that goes beyond a certain } \\
\text { amount }\end{array}$ & $\begin{array}{l}\text { At the cycle level; the shift } \\
\text { between the annual budget } \\
\text { cycle and the discussion on the } \\
\text { performance/the means in the } \\
\text { institutions }\end{array}$ & $\begin{array}{l}\text { For the two types of } \\
\text { construction projects } \\
\text { _ computing, difficulty } \\
\text { to get reference terms } \\
\text { detailed in the delays }\end{array}$ \\
\hline 4) & $\begin{array}{l}\text { Identified } \\
\text { incidents }\end{array}$ & $\begin{array}{l}\text { An important } \\
\text { percentage of } \\
\text { appropriations was } \\
\text { transferred on the } \\
\text { exercise } 2008\end{array}$ & $\begin{array}{l}\text { - Underestimate of certain } \\
\text { projects } \\
\text { - Transfer of important } \\
\text { appropriation since the } \\
\text { beginning of the year }\end{array}$ & $\begin{array}{l}\text { Non respect of forecast } \\
\text { dates of the launching of } \\
\text { calls for tender } \\
\text { 1st trimester: } \\
\text { late launching of calls } \\
\text { for tender for the new } \\
\text { projects (till the end of } \\
\text { January) problem linked } \\
\text { to programming (see risk 2) }\end{array}$ \\
\hline
\end{tabular}




\begin{tabular}{|c|c|c|c|c|}
\hline 5) & Indicators & $\begin{array}{l}\text { - Transfers rate of } \\
\text { inter programs } \\
\text { appropriation } \\
\text { - Abandoned projects } \\
\text { rate }\end{array}$ & $\begin{array}{l}\text { Percentage of projects having } \\
\text { discrepancy between the cost } \\
\text { estimate and the final real cost } \\
\text { (see risk 7) }\end{array}$ & $\begin{array}{l}3 \text { rd trimester: } \\
\text { Late launch of tenders } \\
\text { for new projects (late } \\
\text { January) Problems } \\
\text { related to programming } \\
\text { (see RiskRisk 2) gaps of } \\
\text { inactivity } \\
\text { - Appropriation rate } \\
\text { non delegated at the } \\
\text { end of February }\end{array}$ \\
\hline & & $\begin{array}{l}\text { Risk } 4 \text { : low defining of } \\
\text { needs and evaluation } \\
\text { criteria }\end{array}$ & $\begin{array}{l}\text { Risk } 5 \text { : Lack of technological } \\
\text { and economic monitoring of } \\
\text { the market }\end{array}$ & $\begin{array}{l}\text { Risk } 6 \text { : Failure in the } \\
\text { benefits reception pro- } \\
\text { cedure }\end{array}$ \\
\hline 1) & $\begin{array}{l}\text { Elements } \\
\text { of risks } \\
\text { raised } \\
\text { in the } \\
\text { interview }\end{array}$ & $\begin{array}{l}\text { Incoherence between } \\
\text { expressing need and } \\
\text { determining needs }\end{array}$ & $\begin{array}{l}\text { Absence of extensive technology } \\
\text { and price }\end{array}$ & $\begin{array}{l}\text { - Non involvement of } \\
\text { users } \\
\text { - Non satisfaction }\end{array}$ \\
\hline 2) & Risk detail & $\begin{array}{l}\text { Low defining of needs } \\
\text { and evaluation criteria }\end{array}$ & $\begin{array}{l}\text { Lack of technological and } \\
\text { economic monitoring of the } \\
\text { market }\end{array}$ & $\begin{array}{l}\text { The dysfunction in the } \\
\text { process of services } \\
\text { reception leading to non } \\
\text { conformities : quality, } \\
\text { delay, cost (source of non } \\
\text { satisfaction of users) }\end{array}$ \\
\hline 3) & $\begin{array}{l}\text { Causes of } \\
\text { risk }\end{array}$ & $\begin{array}{l}\text { Absence of clear } \\
\text { distribution of } \\
\text { responsibilities of } \\
\text { defining technical } \\
\text { specifications and } \\
\text { drawing up the } \\
\text { evaluation criterion }\end{array}$ & $\begin{array}{l}\text { Existence of practices } \\
\text { and absence of consistent } \\
\text { procedures, of result } \\
\text { formalization, of systemization } \\
\text { and consistency of practices } \\
\text { on different types of } \\
\text { monitoring: } \\
\text { - Economic monitoring } \\
\text { (quality report, price, } \\
\text { knowing suppliers) } \\
\text { Technologic monitoring } \\
\text { (knowledge of market } \\
\text { offers, technical aspects) }\end{array}$ & $\begin{array}{l}\text { Lack of precision } \\
\text { in the texts in the } \\
\text { operating mode of } \\
\text { reception }\end{array}$ \\
\hline
\end{tabular}


Table 3 (Continued)

\begin{tabular}{|c|c|c|c|c|c|}
\hline 4) & $\begin{array}{l}\text { Identified } \\
\text { incidents }\end{array}$ & $\begin{array}{l}\text { - } \begin{array}{l}\text { Many requests for } \\
\text { clarification }\end{array} \\
\text { - } \begin{array}{l}\text { Fruitless calls for } \\
\text { tender }\end{array} \\
\text { - Bad quality of made } \\
\text { sales }\end{array}$ & & $\begin{array}{l}\text { Purchase of products/services } \\
\text { with prices not in line with } \\
\text { those practiced in the market } \\
\text { Purchase of products/services } \\
\text { of bad quality }\end{array}$ & $\begin{array}{l}\text { Delays in receipt: } \\
\text { Case maintenance } \\
\text { markets (management } \\
\text { of purchasing and } \\
\text { the completion of } \\
\text { receptions by the } \\
\text { external services) }\end{array}$ \\
\hline 5) & Indicators & $\begin{array}{l}\text { Call tender rate } \\
\text { without any offer }\end{array}$ & & $\begin{array}{l}\text { Percentage of purchase } \\
\text { price increase (market price) } \\
\text { of a year to other for the } \\
\text { same product/service (and } \\
\text { justification of these increases) }\end{array}$ & $\begin{array}{l}\text { - Failing reception rate } \\
\text { (completed receptions } \\
\text { but non compliant) }\end{array}$ \\
\hline
\end{tabular}

Risk 7 : Insufficiency of administrative, physi- $\quad$ Risk 8 : Fraud(\& neglect) cal and financial monitoring of projects

\begin{tabular}{lll}
\hline 1) $\begin{array}{l}\text { Elements } \\
\text { of risks } \\
\text { raised }\end{array}$ & - & $\begin{array}{l}\text { Respect of delays } \\
\text { in the } \\
\text { interview }\end{array}$ \\
2) Risk detail & - $\begin{array}{l}\text { Insufficiency in the management of complexity } \\
\text { the completion of late expenditure compared } \\
\text { the initial scheduling hinders MEF. }\end{array}$ \\
& $\begin{array}{l}\text { The management and control of big projects } \\
\text { raises a level of complexity that affects the } \\
\text { execution process of expenditure. }\end{array}$
\end{tabular}

3) Causes of - Lack of formalization of responsibilities and risk

4) Identified incidents
- Delay slippage involving project abandonment (from 20\% to 300\%)

- Direct cost slippage particularly the big projects SI
- Insufficiency in the follow up of stocks and their protection

While circumventing the rule, whether by benefiting from technical opacity of a field or by manipulating the rules related to public markets, one or many operational can organize a personal enrichment

Note : this analysis concentrate mainly on fraud related to public purchases

- Control environment: Lack of communication, training and supervision related to purchasing

- Calls for tender: Lack of tasks separation of public markets

- Payment Lack of information system reducing the manual intervention of actors, allowing placement of automatic control and reporting

- Purchase with an abnormally high price in comparison with the market price 
Table 3 (Continued)

\begin{tabular}{lll}
\hline 5) Indicators & $\begin{array}{l}\text { The following indicators are to be subject to the } \\
\text { global follow up of big projects (see risk 1) }\end{array}$ & $\begin{array}{l}\text { Renewing rate of suppliers for the } \\
\text { calls for tender and purchase orders } \\
\text { (risk 5) }\end{array}$ \\
\hline & the rate for the carryover of appropriations & the
\end{tabular}

\section{Measures of Control and Actions to Reduce the Risks}

In the analysis of delay management processes, control measures have been identified. These measures involve generally imposing the submission of firms to a planning detailing scheduling, task durations and the provided resources. They also involve demanding the clients to adopt a monitoring system that is specific for the management and follow up of practices in order to avoid the mistakes of scheduling as well as of coordination in the study phase and work. This serves also to avoid estimation errors of provisional budget through precautions such as: agreement between ratios and natures of surface, the complete program of technical installations. In order to assure continued control, these measures demand the designation of a control office; its mission is to check the compliance of benefits to specifications. For controlling the construction hazards, a measure has been recommended; it involves integrating to the budget a reasonable reserve to absorb additional costs

The different measures and actions meeting the different major identified risks are summarized in the Appendix 1-8. Performance indicators relating to the various major risks are summarized in the Appendix 9.

\section{Conclusions and Perspectives}

In spite of the fact that a number of works have been done in this field, this is the first to identify and manage the risks in the expenditure process in order to control the deadline slippage and the costs in the construction project. In fact, a detailed list of risks in the expenditure process is present as follow:

R1 : Non alignment of the programs and projects with the strategy

R2 : Failure in the process of budget construction

R3 : Deadline slippage of budget process

R4 : Low defining of needs and evaluation criteria

R5 : Lack of technological and economic monitoring of the market

R6 : Failure in the benefits reception procedure

R7 : Insufficiency of administrative, physical and financial monitoring of projects

R8 : Fraud \& neglect

We can also identify the 40 measures of control and 113 actions to manage the different risks as well as the performance indicators that are related to it. Putting in place such a system of internal control, the owner will contribute to the aspects of delay, the costs and quality in the completion of the projects particularly the construction projects. 
In fact, this internal control system of expenditure process intends to offer to the different stakeholders the reasonable assurance in reaching these objectives all by controlling the set of risks.

The present research allows the production of the main deliverables, they are as follow:

- The mapping of risks

- The portfolio of actions and measures applied to control the risks

- The indicators risk management

However, reaching these objectives determined by this work and the achievement of results in the operational process call for the implication of the set of expenditure actors in the phase "post-project" related to the implementation of the system

In this respect and taking into account the interest of the system in question in terms of controlling the circuit of expenditure, it has been proposed to institutionalize the roles of the different involving parties, by proceeding for example to the appointment of:

- A steering committee that assumes the utter responsibility of the internal control system of the expenditure process particularly in signing an annual statement

- A coordinator of internal control that animates the internal control of the expendi- ture process: assist with the coordination of different players and sharing the good practices between risks monitoring in a way to control the 15 risks and to implement the actions of internal control.

- Risks monitoring responsible for supervising the implementation of progress actions related to risks that must be assured the monitoring

- Internal control referents that animates the internal control of the expenditure process in its own Management Center

Other concrete measures can be used to control the risks of expenditure particularly in setting up a committee of discharges; it is by defining a threshold that shall not be exceeded for the sale and by defining a composition of members of a reception committee of offered services

Indeed, the success of the implementation phase requires an important mobilization and an efficient implication of the set of involving parties in the expenditure in order to control the set of identified risks.

It is worth referring to the actions of change management and the subsequent adoption to the profit of managers by the means of communication activities, of sensitization and training must be planned to promote the implementation of this framework .

\section{References}

Ajanlekoko. J. O. 1987. Controlling cost in the construction industry. Lagos QS Digest 1(1): 8-12. Lagos

Alaghbari, W., M.R.A. Kadir, A. Salim, and Ernawati. 2007. The significant factors causing delay of building construction projects. Malaysia. Engineering, Construction and Architectural Management 14 (2): 192- 206.

Albinu, A. A., and G. O. Jagboro. 2002. The effects of construction delays on project delivery in Nigerian construction industry .International Journal of Project Management 20: 593-599. 
Al-Barak, A. A. 1993. Causes of contractors_failures in Saudi Arabia. Master Thesis. CEM Dept., KFUPM. Dhahran, Saudi Arabia.

Al-Ghafly, M. A. 1995. Delays in the construction of public utility projects in Saudi Arabia. Master Thesis. CEM Dept., KFUPM, Dhahran, Saudi Arabia.

Assaf, S. A, M. Al-Khalil, M. Al-Hazmi. 1995. Causes of delays in large building construction projects. ASCE J Manage Eng 11 (2): 45-50.

Al-Momani, A. H. 2000. Construction delay: A quantitative analysis. International Journal of Project Management 18: 51-59.

Assaf, S. A., and S. Al-Hejji. 2006. Causes of delay in large construction projects. International Journal of Project Management 24: 349-357.

Belassi, W., and O. I. Tukel. 1996. A new framework for determining critical success/failure factors in projects. International Journal of Project Management 14 (3): 141-51.

Challal, A., and M. Tkiouat. 2012. Identification of the causes of deadline slippage in construction projects: State of the art and application. Journal of Service Science and Management 5 (2): 151-159. doi: 10.4236/jssm.2012.52019.

Challal, A., and M. Tkiouat. 2012. Qualitative approach risk period in construction projects. Journal of Financial Risk Management 1: 42-51. doi: 10.4236/jfrm.2012.13008.

Challal, A., and M. Tkiouat. 2012. The design of cost estimating model of construction project: Application and simulation. Open Journal of Accounting 1 (1): 15-26. doi: 10.4236/ojacct.2012.11003.

Chan D. W., and M. M. Kumaraswamy. 1997. A comparative study of causes of time overruns in Hong Kong construction projects. Int J Project Manage 15 (1): 55-63.

El-Razek, M. E. A., H. A. Bassioni, and A. M. Mobarak. 2008. Causes of delay in building construction projects in Egypt. Journal of Construction Engineering and Management 134 (11): 831-841.

Enshassi, A., J. Al-Najjar, and M. Kumaraswamy. 2009. Delays and cost overruns in the construction projects in the Gaza Strip. Journal of Financial Management of Property and Construction 14 (2): 126-151.

Faridi, A. S., and S.M. EL-Sayedgh. 2006. Significant factors causing delay in the UAE construction industry. Construction Management and Economics 24: 1167-1176.

Frimponga, Y., J. Oluwoyeb, and L. Crawfordc. 2003. Causes of delay and cost overruns in construction of groundwater projects in a developing countries: Ghana as a case study. International Journal of Project Management 21: 321-326.

Hamidreza. A., S. Khosravi, A. Ghorbanali, M. Borzabadi, and M. Valipour, 2010. Identification of Causes of Non-excusable Delays of Construction Projects: 42-46. International Conference on E-Business Management and Economics, Hong Kong, 28-30.

Hatush, Z., and M. Skitmore. 1997. Evaluating contractor prequalification data: selection criteria and project success factors. Construction Management and Economics 15 (2): 129-47.

Afshari, H., S. Khosravi, A. Ghorbanali, M. Borzabadi, and M. Valipour. 2010. Identification of causes of non-excusable delays of construction projects. International Conference on E-business, Management and Economics IPEDR 3. C IACSIT Press, Hong Kong. 
Koushk, P. A., A. K. Al-Rashid, and N. Kartam. 2005. Delays and cost increases in the construction of private residential projects in Kuwait. Construction Management and Economics 23: 285-294.

Kaming, P., P. Olomolaiye, G. D. Holt, and F. C. Harris. 1997. Factors influencing construction time and cost overruns on high-rise projects in Indonesia. Construct Manage Econom;15:83-94.

Kumaraswamy, M, and D. Chan. 1998. Contributors to construction delay. Construct Manage Econom 16 (1):17-29.

Kaliba, C., M. Muya, and K. Mumba. 2009. Cost escalation and schedule delays in road construction projects in Zambia. International Journal of Project Management 27: 522-531.

Lim, C. S., and M. Z. Mohamed. 2000. An exploratory study into recurring construction problems. International Journal of Project Management 18 (4): 267-73.

Long, N. D., S. Ogunlana, T. Quang, and K. C. Lam. 2004. Large construction projects in developing countries: a case study from Vietnam. International Journal of Project Management 22 (7): 553-61.

Le-Hoai, L., Y. D. Lee, and J. Y. Lee, 2008. Delay and cost overruns in Vietnam large construction projects: A comparison with other selected countries. Journal of Civil Engineering 12 (6): 367-377.

Lo, T. Y., I. W. H. Fung, and K. F. C. Tung. 2006. Construction delays in Hong Kong civil engineering projects. Journal of Construction Engineering and Management 6: 636-649.

Meeampol, S., and S. O. Ogunlana. 2006. Factors affecting cost and time performance on highway construction projects: evidence from Thailand. Journal of Financial Management of Property and Construction 11 (1): 3-20.

Haseeb, M., L. Xinhai, A. Bibi, M.-ud, Dyian, and W. Rabbani. 2011. Causes and effects of delays in large construction projects of Pakistan. Kuwait Chapter of Arabian Journal of Business and Management Review 1 (4): 18.

Noulmanee. A, J. Wachirathamrojn, P. Tantichattanont, and P. Sittivijan. 1999. Internal Causes of Delays in Highway Construction Projects in Thailand. www.ait.c1et.com, July.

Odeyinka, H. and A, Yusif. 1997. The causes and effects of construction delays on completion cost of housing projects in Nigeria. Journal of Financial Management of Property and Construction 2 (3): 31-44.

Ogunlana, S. O., K. Promkuntong, and V. Jearkjirm. 1996. Construction delays in a fast-growing economy: Comparing Thailand with other economies. International Journal of Project Management 14 (1): 37-45. Elsevier.

Odeh, A. M., and H. T. Battaineh. 2002. Causes of construction delay: Traditional contracts. International Journal of Project Management 20: 67-73.

Sambasivan, M., and Y. W. Soon. 2007. Causes and effects of delays in Malaysian construction industry. International Journal of Project Management 25: 517-526.

Sweis, G., R. Sweis, A. A. Hammad, and A. Shboul. 2008. Delays in construction projects: The case of Jordan. International Journal of Project Management 26: 665-674.

Tumi, S. A. H., A. Omran, and A. H. K. Pakir. 2009. Causes of Delay in Construction Industry in Libya. The International Conference on Economics and Administration, Faculty of Administration and Business, University of Bucharest, Romania ICEA - FAA Buchares, 14-15th (November). 
Toor. S. U. R., and S. O. Ogunlana. 2008. Problems causing delay in major construction projects in Thailand. Construction Management and Economics 26: 395-408.

Towhid, P. and I. Amiruddin. 2011. Significant factors causing and effects of delay in Iranian construction projects. Australian Journal of Basic and Applied Sciences 5 (7): 450-456.

Ubaid, A. G. 1991. Factors affecting contractor performance. Master Thesis. CEM Dept., KFUPM, Dhahran, Saudi Arabia.

Walker, D. H. T. 1995. An investigation into construction time performance. Construction Management and Economics 13 (3): 263-74.

Walker, D. H. T. 1996. The contribution of the construction management team to good construction time performance - an Australian experience. Journal of Construction Procurement 2 (2): 4-18.

Zaneldin, E. K. 2006. Construction claims in United Arab Emirates: Types, causes, and frequency. International Journal of Project Management 24: 453-459. 
Appendix 1. Measures of Control and Actions to Reduce the Risk R1

Measures

Actions

R1 : Non alignment of the programs and projects with the strategy

Put in place a strategic planning intending (based on action plan, guidance note and developing analytic review) intending to synchronise the budgetary and strategic schedules

Create an instance for the resources Directors + divisions of management control and having a vocation to give its opinion on coherence/ compliance of the budgetary orientations with the strategy

Structure the control function of management 'network'
R1.A1 - write and publish a note signed by the Minister/ the Secretary General demanding a real dialogue of harmonized management in the MEF

R1.B1 - create a consultative committee of projects plus a budgetary allocation that can be a binding force for the five management centers

R1.C1 (QW) -harmonize the perception of control function of management and communicate via the meeting the sensitization of actors 
Appendix 2. Measures of Control and Actions to Reduce the Risk R2

Measures

Actions

R2 : Failure in the process of budget construction

Put in place a plan allowing to appreciate the project in comparison to its justification by a precise and reliable analysis

Learn from the experience of the budgetary execution of the exercise $n-1$

Anticipate the budgetary programming process
R2.A1 - Define the main principles to be followed in order to make budgetary estimates based on common references

R2.A2 - Define a model of fact sheets of budgetary construction

R2.B1 (QW) - Define the analysis to be made in the analytical review taken on the exercise clos N-1

R2.B2 (QW) -Identify the actors and the timing of analytical reviews

R2.B3 (QW) - Define the alert thresholds on the transfers and reports

R2.C1 - Define and formalize a unique and common schedule of management (see R1.A4) 
Integrate the project planning on the medium term
R2.D1 (QW) - Include the CDMT in the unique, common and annual schedule of management (see R1.A4)

R2.D2 -Define the procedure of contracting between the sub-authorizing officer and the DAAG in the process of budget construction

Appendix 3. Measures of Control and Actions to Reduce the Risk R3

Measures

\section{R3 : Deadline slippage of budget process}

The requests of delegations coming from the subauthorizing officer must reach the authorizing officer at the start of January

The requests of delegations coming from sub-authorizing officer no later than Januaryprovided that the risk 2 is to be controlled

Delegation by the authorizing officers to sub-authorizing officers to the level of 80 percent on 15 February

Fixation by the minister of the delays linked to the production of detailed reference terms
R3.A1 (QW) - Add an availability on the deadline of the reception of the requests of delegation to the note of the minister on the delay of 30 June

R3.A2 - Write and disseminate a note limiting the transfers to a threshold to define according to the planned actions

R3.A3 - Offer the necessary justifications for all the exceptional requests of delegation compared to the programming

R3.B1 - Identify the motives of delays in the clearance of accountancy in the exercise N-1 and identify the actions particularly at the level of information system to allow the close of the budgetary exercise plus the late of 30 January

R3.C1 (QW) - Write and disseminate a note of the minister consisting on terms of detailed references before the end of June of the year N-1 for a category of projects 
Systemize the evaluation of delays of budgetary process and its execution and to put in place the adjustment actions

Systemize the reporting and the budgetary follow up of available appropriations
R3.D1 (QW) - Identify reporting states/indicators that must be produced by the information system on the key stages of the process

R3.E1 (QW) - Propose the specifications SI of fields allowing to qualify the available types of appropriations and to restrict the use of the following appropriations

Appendix 4. Measures of Control and Actions to Reduce the Risk R4

Measures

R4 : low defining of needs and evaluation criteria

Develop a definition guide of the need (facilitate and harmonize the practices) Database by the type of the expenditure

Professionalize the buyers/ prescribers
R4.A1 - Identify the key articles making the link between the technical and administrative aspects and produce a reference document on the articles for each type of benefit

R4.B1 - Predict a training for buyers on the reference document and on the key articles for each big type of benefit 
Promote the expertise and multidisciplinary exchange between actors and promote forum exchange

Harmonies/clarify the evaluation of recipients
R4.C1 - Create a body in charge of data base in the exchange committee and of coordination that centralizes the set of observations of monitoring that communicates periodically the key lessons to the management centers

R4.D1 -Identify the main evaluation criteria by benefit type, test them and produce a reference document available to the set of management centers

Appendix 5. Measures of Control and Actions to Reduce the Risk R5

Measures

R5 : Lack of technological and economic monitoring of the market

Put in place the

communication actions and

exchange of good practices

(buyers forum)

Create a database of the $3 \mathrm{P}$

(Price, Product, Provider)

Promote judicial monitoring

Clarify the roles and responsibilities of each (separation of tasks)
R5.A1 - Organize a dialogue space and work between actors in the purchase process

R5.A2 - Identify the exchange opportunities of good practices purchase of external actors

R5.B1 - Define a centralized suppliers data base dealing with the internal evaluation of service providers

R5.C1 - Define the modalities of judicial monitoring allowing to identify and communicate the regulatory changes

R5.D1 (QW) - Formalize a procedure that separates the roles buyer/prescriber and describe the relationships between these two actors 
Recruit/train the public buyers

Experiment a monitoring unit having the vocation to be deployed

Getting ideas on the evaluation model of the performance linked to purchases

Integrate the feedback in the process of suppliers selection
R5.E1 - Target the training actions destined to public buyers in order to reinforce the competencies

R5.E2 - Plan a communication action that valorize the purchase function and seems to attract the competencies and to present the function to other actors

R5.F1 (QW) - Define the attributions of a monitoring team

R5.G1 - Identify the evaluation indicators of purchase performance

R5.H1 - Organize an exchange meeting with the suppliers allowing to make an annual balance of provisional program of purchases

Appendix 6. Measures of Control and Actions to Reduce the Risk R6 
Better organize/structure the reception of benefits: role clarification/involvement of manager, of buyer, competent head of service, separation of tasks between command/reception/payment, rationalization of the work load

Clarify/explain the terms/ conditions of receipt (Commission of receipt: role, composition, scope/nature of purchases.)

Enrich the clauses dealing with the reception in the CCAG
R6.A1 (QW) - Set up a unique and common operating mode of reception by major categories of benefits

R6.A2 - Set up an evaluation procedure of enterprises after the benefit

R6.B1 (QW) - Identify the reception committees types according to the categories of benefits and the importance of the project (failing case)

R6.C1 - Set up a CCAG for each type of benefits with a clause indicating the major principles to observe in the reception

Appendix 7. Measures of Control and Actions to Reduce the Risk R7

Measures

\section{R7 : Insufficiency of administrative, physical and financial monitoring of projects}

Define portfolio of projects to be put under observation (sum, complexity, Define a "profile"/portfolio of projects to be under observation (amount, complexity, value added)
R7.A1 (QW) - Define the criterion of projects classification to identify major projects

R7.A2 (QW) - Formalize the portfolio of major projects and determine the arbitration responsibilities and update

R7.A3 (QW) - Create a committee in charge of the global follow up of major projects 
Synchronies/integrate strongly the different actors

Create a function 'project manager' dedicated and assuring his professionalism (training, awareness)

Promote the necessary tools to projects steering (train the project managers to its use): scoreboard, follow up, supervision

Structure/harmonize the principal project governance (on the basis of good practices, steering committee, follow up committee, contractual committees)
R7.B1 (QW) - Define major categories of projects and the stages of each category in order to identify the grounds of coordination between actors

R7.C1 (QW) - Write a file of project manager and identify potential ground of manger project

R7.D1 - Design a scoreboard that can be adapted, it must be communicated with actors and prove the key indicators

R7.E1 (QW) - Define an organization type of governance project

R7.E2 - Write a chart of project management

\section{Appendix 8. Measures of Control and Actions to Reduce the Risk R8}

\section{Measures}

\section{Actions}

\section{R8 : Fraud \& neglect}

Assure an environment control to fight against fraud and neglect

Determine and formalize the major points of vulnerability of the expenditure in comparison to the risk of fraud
R8.A1- Write a deontological guide of expenditure flows signed by the Directors of 5 management centers

R8.A2- Organize a training action on the fraud involving the directors of Resources of expenditure process

R8.B1- Identify and formalize by the purchase sub-process 
Plan margins of discretion of the actors of the expenditure

Organize the sensitive functions

Sensibilise the actors to fraud mechanisms (internal and external) specific to each job of the expenditure

Put in place the process of professional alert ("Whistleblowing")

Better define the role of the internal audit as an evaluator of internal control unit related to combat fraud (preventive, detective)
R8.C2- identify the measures of backing the discretionary margins, according to two possible logics: 1 - Set up reporting making actors responsible 2 - Definition and communication of detailed procedures limiting the power of actors

R8.D1 (QW) - Inventory the sensible functions of expenditure process

R8.E1- Organize a training on the fraud (internal and external) to operational destination of expenditure flow

R8.F1- Define the concerned perimeters by the professional alerts

R8.G1 (QW) - Define the role limits of internal audit in comparison to the plan against the fraud 
Appendix 9. Indicators of Performance

Name of the Indicator

Formula

Transfer rate of inter-program appropriation (BI*) in 2011

The total appropriation carried over

Transfer rate of intra-program BI appropriation

The total of non assigned appropriations

Engagement rate

The average delay between the attribution and the starting of the service in 2011

Unsuccessful tendering procedures

Renewal suppliers rate in the purchasing order

The rate of emission (BI) in $31 / 12 / 2011$

The execution stops rate of markets

*BI: The investment budget 2011 (BI) in 2011 priated amount BI in 2011

$1^{\text {st }}$ Trimester BI to delegate in 2011

$2^{\text {nd }}$ Trimester BI to delegate in 2011 work date OS in 2011 total supplier(2011) tions 2011
Risks Covered

by the Indicator

R1, R2

R1, R7

The amount of appropriation carried over (2010/2011)/the total appropriated amount

The total transfer of intra-program appropriation(BI) in 2011 /the total appro-

The amount of non assigned appropriations in 30 March 2011/the total appropriations

The amount of non assigned appropriations in 30 March 2011/the total appropriations

The Total appropriation committed (BI)/ the Total definitive appropriations (BI)

The average delay between the display of results of $\mathrm{AO}$ attributed and the starting of

Number of Unsuccessful tendering procedures 2011/No. Number of Unsuccessful tendering procedures showed 2011

The amount of emissions (BI) in 31/12/ $2011 /$ the total Total definitive appropria-

Accumulated delay of stops/the total contractual delay of the approved markets in
R4, R5

R5, R8

R7,R6

R7, R6, R8

R2, R3, R7

R3, R2, R5, R7,

$$
\mathrm{R} 7, \mathrm{R} 6, \mathrm{R} 8
$$

